\title{
Total Synthesis of (-)-Pseudolaric Acid B
}

\author{
Barry M. Trost ${ }^{*}$, Jerome Waser, and Arndt Meyer \\ Department of Chemistry, Stanford University, Stanford, California 94305-5080
}

Pseudolaric acids B and A (1a and $\mathbf{1 b}$, Scheme 1) are diterpene acids isolated from the extract of the root bark of Pseudolarix kaempferi Gordon (pinaceae), which is also used in tujinpi, a traditional Chinese medicine for the treatment of fungal infections of the skin and nails. ${ }^{1}$ Pseudolaric acid B (1a) has been identified as a potent antifungal, antifertility and cytotoxic agent, displaying much higher activity than pseudolaric acid A (1b). ${ }^{2}$ More recently, the discovery that pseudolaric acid B (1a) displays significant activity against multi-drug resistant cancer cell lines has revitalized interest in this natural product. ${ }^{3}$

Pseudolaric acid B (1a) displays a compact tricyclic core which includes a fused [5-7] ring system (polyhydroazulene) with an unusual trans substitution pattern at the ring fusion site (C4-C10) and 4 contiguous stereocenters, one of them being quaternary (C10). Taken together, these structural features make pseudolaric acid B (1a) a challenging substrate for modern synthetic chemistry. As a result, several approaches towards the pseudolaric acids have been published. ${ }^{4}$ In 2006, the unique successful synthesis of pseudolaric acid A (1b) was reported based on a carbene cyclization cycloaddition cascade to build the polyhydroazulene core. ${ }^{4 \mathrm{~h}}$ Herein, we report the first asymmetric synthesis of pseudolaric acid B (1a) highlighting the use of a metal-catalyzed [5+2] cycloaddition and an intramolecular alkoxycarbonyl radical addition to construct the ring system.

The $\mathrm{Rh}$ and Ru catalyzed [5+2] intramolecular cycloaddition reaction of an alkyne and a vinylcyclopropane developed by Wender ${ }^{5}$ and us ${ }^{6}$ respectively is ideally suited for accessing the polyhydroazulene core of pseudolaric acid B (1a). To reveal this key structure in the natural product, we envisioned a late stage introduction of the C13-C17 side chain (Scheme 1). An intramolecular alkoxycarbonyl radical addition to the C9-C10 double bond of intermediate 2 was planned for the installation of the quaternary center. Adjustment of the oxidation state and double bond isomerization leads to 1,4-diene $\mathbf{3}$, which would result from an intramolecular [5 +2 ] cycloaddition reaction of easily accessible precursor 4 .

The synthesis of precursor $\mathbf{4}$ for the [5+2] cycloaddition reaction is shown in Scheme 2. Iodide 7 was synthesized in 5 steps and $62 \%$ overall yield from 2-acetylbutyrolactone (5), using Noyori reduction to install the adjacent stereocenters. ${ }^{7}$ Aldehyde 9 was obtained in 3 steps and $84 \%$ overall yield from cis-butenediol (8) via Charette cyclopropanation. ${ }^{8}$ Homologation of iodide 7, followed by Schlosser-Wittig olefination with aldehyde $\mathbf{9}$ and deprotection gave vinylcyclopropane 4 with 10:1 E/Z selectivity.

We then proceeded to examine the key [5+2] cycloaddition reaction (Scheme 2). Using [CpRu $\left.\left(\mathrm{CH}_{3} \mathrm{CN}\right)_{3}\right]^{+} \mathrm{PF}_{6}{ }^{-}$(11), $23 \mathrm{~mol} \%$ catalyst was needed to obtain full conversion. The desired polyhydroazulene 3 was isolated with 15:1 diastereoselectivity but only $48 \%$ yield. Conjugated diene 10 was also obtained in $15 \%$ yield. We speculated that the insertion of the Ru catalyst in the labile bisallylic $\mathrm{C}-\mathrm{H}$ bond leads to a Ru pentadienyl complex, which then deactivates the catalyst. Diene $\mathbf{1 0}$ then is a consequence of protonation upon work up. We expected $\mathrm{Rh}$

E-mail: bmtrost@stanford.edu. 
catalysts to be less prone to this undesired side reaction. Indeed, $\left[\left(\mathrm{C}_{8} \mathrm{H}_{10}\right) \mathrm{Rh}(\mathrm{COD})\right]^{+} \mathrm{SbF}_{6}{ }^{-}$ (12) $5 \mathrm{~b}$ gave the desired product 3 exclusively in $88 \%$ isolated yield, although the reaction still required an unusually high catalyst loading (11 mol\%).

A novel method for the regioselective isomerization of 1,4-diene 3 to a 1,3-diene $\mathbf{1 3}$ was then examined (Scheme 3). Activation of TBAF with molecular sieves provided a reagent that affected desilylation as well as isomerization to conjugated diene 13 in $94 \%$ yield. ${ }^{9}$ Protection of diol 13 allowed for a diastereoselective epoxidation of the tetrasubstituted double bond. Vinylogous eliminative opening of the resulting epoxide mediated by LDA completed the installation of the $\mathrm{C} 4$ alcohol of pseudolaric acid B (1a). Oxidation of the allylic silyl ether of the resultant diene $\mathbf{1 4}$ followed by deprotection provided diol $\mathbf{2}$.

At this point, we turned towards introduction of the C13-C17 side chain and the quaternary center at $\mathrm{C} 10$ (Scheme 3). We intended to apply a rarely used alkoxycarbonyl radical cyclization 10 to construct the quaternary center. The most direct approach would be to introduce a side chain precursor prior to cyclization. To examine this route, we synthesized alkoxycarbonyl selenium 15 bearing an alkyne group as side chain precursor in 4 steps from diol 2. Cyclization of $\mathbf{1 5}$ resulted only in decomposition and decarboxylation. We concluded that formation of a tertiary propargylic radical was favored over cyclization. As an alternative strategy, secondary alkoxycarbonyl selenium 16 was synthesized. Gratifyingly, cyclization of 16 proceeded smoothly to give a mixture of double bond isomers. Treatment with DBU resulted in exclusive formation of the desired conjugated ester 17.

To complete the synthesis, opening the lactone was necessary for the introduction of the side chain (Scheme 4). To prevent lactonization back to 17, KOTMS was used for the hydrolysis of the lactone followed by methylation with dimethyl sulfate under buffered conditions and immediate oxidation. Removal of the PMB group was necessary before introduction of an acetylene as side chain precursor, as elimination to the conjugated ketone was observed otherwise. Using soluble $\mathrm{RCeCl}_{2} \cdot 2 \mathrm{LiCl}^{11}$ was essential to allow full conversion at $-78{ }^{\circ} \mathrm{C}$. At higher temperature a retro-aldol reaction became favored. Complete selectivity was observed in the formation of the C11-alcohol, as expected by a Felkin-Ahn approach on ketone $\mathbf{1 8}$. Lactonization to tricycle 19 was achieved using Otera's catalyst. ${ }^{12}$ Deprotection of the terminal acetylene, acetylation, hydrostannylation, and Stille coupling with known iodide $21^{13}$ completed the total synthesis of pseudolaric acid B (1a). All physical and spectroscopic data were in agreement with the published values for natural pseudolaric acid B (1a) (melting point, optical rotation, ${ }^{1} \mathrm{H}$ and ${ }^{13} \mathrm{C}$ NMR, IR and mass). ${ }^{2 \mathrm{a}, 2 \mathrm{c}}$

In summary, we report the asymmetric synthesis of pseudolaric acid B (1a) based on a metalcatalyzed [5+2] cycloaddition reaction to build the polyhydroazulene core directly from a simple linear precursor and a selective access to a 1,3-diene from the initially formed 1,4 diene. An efficient alkoxycarbonyl radical cyclization and a highly selective cerium acetylide addition were additional key steps towards the stereoselective formation of the tricyclic core of pseudolaric acid B (1a).

\section{Supplementary Material}

Refer to Web version on PubMed Central for supplementary material.

\section{Acknowledgements}

We thank the NSF and the NIH (GM13598) for their generous support of our programs. J. W. thanks the Swiss National Science Foundation and the Roche Research Foundation for postdoctoral fellowships. A. M. thanks the German Academic Exchange Service (DAAD) for a postdoctoral fellowship. Mass spectra were provided by the Mass 
Spectrometry Regional Center of the University of California, San Francisco, supported by the NIH Division of Research Resources. We thank Johnson Matthey for a generous supply of palladium and ruthenium salts.

\section{References}

1. (a) Yao JX, Lin XY. Acta Chim Sin (Engl Ed) 1982;40:385. (b) Zhou BN, Ying BP, Song GQ, Chen ZX, Han J, Yan YF. Planta Med 1983;47:35. [PubMed: 17405089]

2. (a) Hamburger MO, Shieh HL, Zhou BN, Pezzuto JM, Cordell GA. Magn Reson Chem 1989;27:1025. (b) Zhang YL, Lu RZ, Yan AL. Acta Pharmacol Sin 1990;11:60. (c) Li EG, Clark AM, Hufford CD. J Nat Prod 1995;58:57. [PubMed: 7760078]

3. Wong VKW, Chiu P, Chung SSM, Chow LMC, Zhao YZ, Yang BB, Ko BCB. Clin Cancer Res 2005;11:6002. [PubMed: 16115945]

4. (a) Pan BC, Chang HY, Cai GL, Guo YS. Pure Appl Chem 1989;61:389.Higuchi, RI. PhD Thesis. Stanford University; 1995. (c) Chiu P, Chen B, Cheng KF. Tetrahedron Lett 1998;39:9229. (d) Hu YH, Ou LG, Wang XL, Bai DL. Chin Chem Lett 1999;10:281. (e) Chiu P, Chen B, Cheng KF. Org Lett 2001;3:1721. [PubMed: 11405695] (f) Jiang XT, Ou LG, Han DM, Zhai YF, Bai DL. Chin Chem Lett 2001;12:113. (g) Wu BG, Karle JM, Watkins EB, Avery MA. Tetrahedron Lett 2002;43:4095. (h) Geng Z, Chen B, Chiu P. Angew Chem, Int Ed 2006;45:6197.

5. (a) Wender PA, Takahashi H, Witulski B. J Am Chem Soc 1995;117:4720. (b) Wender PA, Williams TJ. Angew Chem, Int Ed 2002;41:4550.

6. (a) Trost BM, Toste FD, Shen H. J Am Chem Soc 2000;122:2379. (b) Trost BM, Shen HC, Horne DB, Toste ED, Steinmetz BG, Koradin C. Chem Eur J 2005;11:2577.

7. Mashima K, Kusano KH, Sato N, Matsumura Y, Nozaki K, Kumobayashi H, Sayo N, Hori Y, Ishizaki T, Akutagawa S, Takaya H. J Org Chem 1994;59:3064.

8. Charette AB, Juteau H, Lebel H, Molinaro C. J Am Chem Soc 1998;120:11943.

9. All attempts to perform the isomerization with protected alcohols were unsuccessful indicating likely the intramolecular participation of an alkoxide in the deprotonation of the bisallylic proton.

10. (a) Singh AK, Bakshi RK, Corey EJ. J Am Chem Soc 1987;109:6187. (b) Bachi MD, Bosch E. J Org Chem 1992;57:4696.

11. Krasovskiy A, Kopp F, Knochel P. Angew Chem, Int Ed 2006;45:497.

12. Otera J, Danoh N, Nozaki H. J Org Chem 1991;56:5307.

13. Baker R, Castro JL. J Chem Soc, Perkin Trans 1 1990:47. 


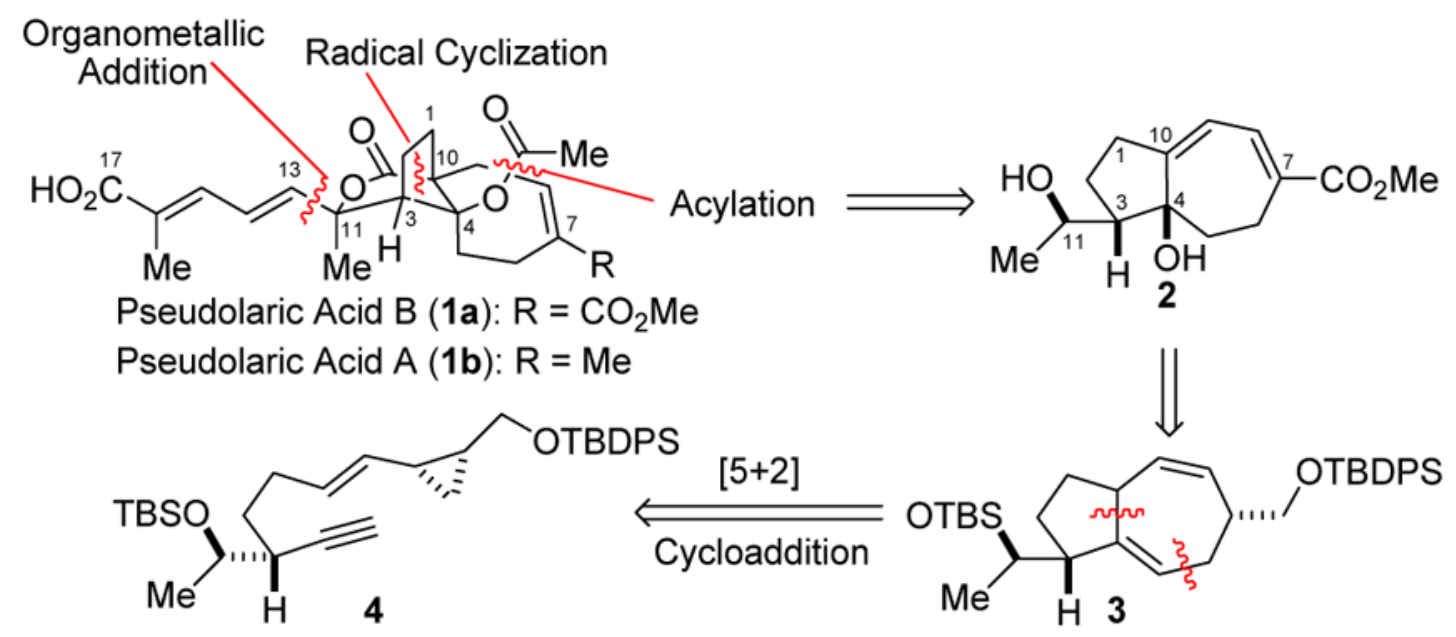

Scheme 1.

Retrosynthesis of Pseudolaric Acid B (1a) 


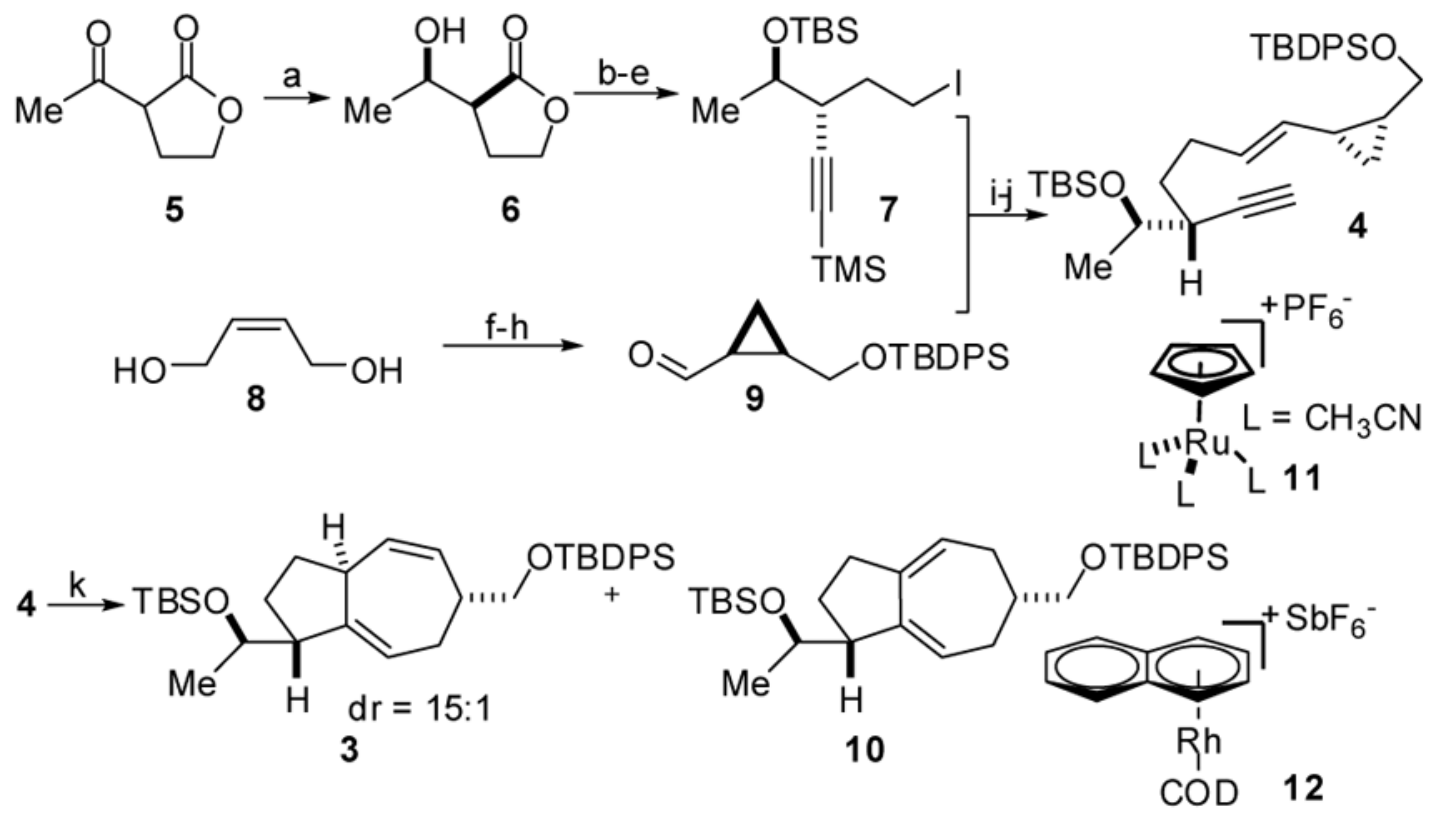

Scheme 2.

Synthesis of the Polyhydroazulene Core ${ }^{\mathrm{a}}$

${ }^{a}$ Conditions: (a) $1.4 \mathrm{~mol} \%\left[\mathrm{RuI}_{2} \text { ( } p \text {-cymene) }\right]_{2}, 2.8 \mathrm{~mol} \%(R)$-BINAP, $1800 \mathrm{psi}_{2}$, methanol, $\mathrm{CH}_{2} \mathrm{Cl}_{2}, 40^{\circ} \mathrm{C}, 95 \%,>95: 5 \mathrm{dr},>90 \%$ ee. (b) TBSCl, imidazole, DMAP, DMF. (c) DIBALH, toluene, $-78{ }^{\circ} \mathrm{C}$. (d) $\mathrm{TMSCHN}_{2}$, LDA, THF, $-78{ }^{\circ} \mathrm{C}$, then TMSCl, $73 \%$ over 3 steps. (e) $\mathrm{PPh}_{3}, \mathrm{I}_{2}$, imidazole, toluene, 90\%. (f) TBDPSCl, imidazole, THF, 92\%. (g) Et $2 \mathrm{Zn}, \mathrm{DME}$, $\mathrm{CH}_{2} \mathrm{I}_{2}$, Charette's auxiliary, ${ }^{8} \mathrm{CH}_{2} \mathrm{Cl}_{2},-10 \rightarrow 23{ }^{\circ} \mathrm{C}, 91 \%$, >90\% ee. (h) $(\mathrm{COCl})_{2}$, DMSO, $\mathrm{NEt}_{3}, \mathrm{CH}_{2} \mathrm{Cl}_{2}$, quant. (i) 1) $\mathrm{MePh}_{3} \mathrm{P}^{+} \mathrm{Br}^{-}, \mathrm{PhLi} / \mathrm{LiBr}, \mathrm{THF}$; 2) $7,0{ }^{\circ} \mathrm{C}$, then $\mathrm{PhLi} / \mathrm{LiBr}$; 3) 9, $-78{ }^{\circ} \mathrm{C}$, then $\mathrm{PhLi} / \mathrm{LiBr}, 23{ }^{\circ} \mathrm{C}$; 4$) \mathrm{HCl},-78^{\circ} \mathrm{C}$, then $\mathrm{KO}{ }^{t} \mathrm{Bu}, 23^{\circ} \mathrm{C}$. (j) $\mathrm{K}_{2} \mathrm{CO}_{3}, \mathrm{MeOH}, 58 \%$ over 2 steps $(53 \%(E)-4)$. (k) $23 \mathrm{~mol} \%\left[\mathrm{CpRu}\left(\mathrm{CH}_{3} \mathrm{CN}\right)_{3}\right]^{+} \mathrm{PF}_{6}{ }^{-}$(11), acetone, $48 \%$ 3, $15 \%$ 10 or $11 \mathrm{~mol} \%\left[\left(\mathrm{C}_{8} \mathrm{H}_{10}\right) \mathrm{Rh}(\mathrm{COD})\right]^{+} \mathrm{SbF}_{6}{ }^{-}$(12), DCE, 88\% 3. 
<smiles>CC(O)[C@H]1CCC2=C1CC[C@H](CO)C=C2</smiles>

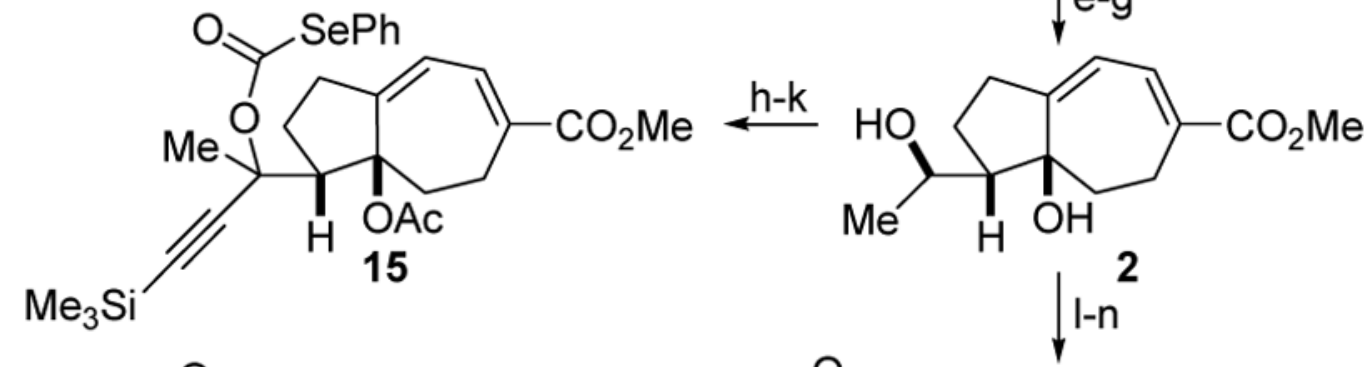

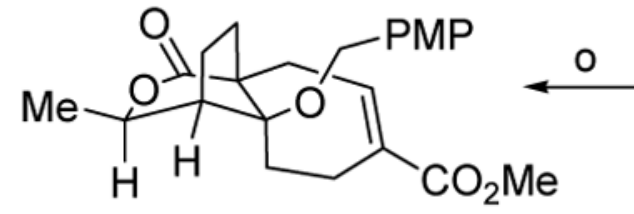

17

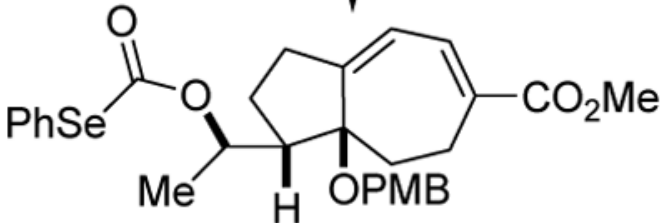

16

Scheme 3.

Introduction of the Quaternary Center ${ }^{\mathrm{a}}$

${ }^{\mathrm{a} C}$ Conditions: (a) TBAF, $3 \AA$ MS, THF, 94\%. (b) TESCl, imidazole, DMAP, DMF, 85\%. (c) $m$-CPBA, $\mathrm{NaHCO}_{3}, \mathrm{CH}_{2} \mathrm{Cl}_{2},-20{ }^{\circ} \mathrm{C}$. (d) LDA, THF, $0{ }^{\circ} \mathrm{C}, 72 \%$ over 2 steps. (e) DDQ, pH=7 buffer, $\mathrm{CH}_{2} \mathrm{Cl}_{2}$. (f) $\mathrm{MnO}_{2}, \mathrm{KCN}, \mathrm{AcOH}, \mathrm{MeOH}, 85 \%$ over 2 steps. (g) TBAF, AcOH, THF, $87 \%$. (h) Dess-Martin periodinane, $\mathrm{CH}_{2} \mathrm{Cl}_{2}, 85 \%$. (i) $\mathrm{Ac}_{2} \mathrm{O}$, pyridine, DMAP, quant. (j) $\mathrm{TMSC} \equiv \mathrm{CCeCl}_{2}, \mathrm{THF},-78^{\circ} \mathrm{C}$, then CDI, $-78 \rightarrow 23{ }^{\circ} \mathrm{C}, 91 \%, 8: 1 \mathrm{dr} .(\mathrm{k}) \mathrm{Ph}_{2} \mathrm{Se}_{2}, \mathrm{NaBH}_{4}, \mathrm{DMF}$, $76 \%$ (84\% brsm). (1) CDI, THF, quant. (m) $\mathrm{Ph}_{2} \mathrm{Se}_{2}, \mathrm{NaBH}_{4}, \mathrm{DMF}, 92 \%$. (n) PMBOC(NH) $\mathrm{CCl}_{3}, 2 \mathrm{~mol} \% \mathrm{Sc}(\mathrm{OTf})_{3}$, toluene, $0{ }^{\circ} \mathrm{C}, 94 \%$. (o) $\mathrm{Bu}_{3} \mathrm{SnH}, 1,1^{\prime}$-azo(biscyclohexane carbonitrile), benzene, $70{ }^{\circ} \mathrm{C}$, then $\mathrm{DBU}, 23^{\circ} \mathrm{C}, 85 \%$ (92\% purity). 


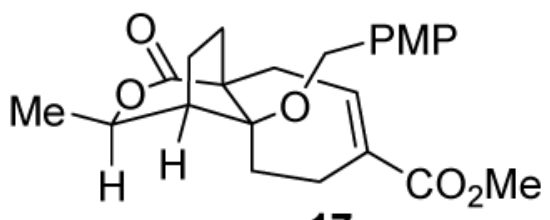

17<smiles>CCCCCC(=O)CO</smiles>
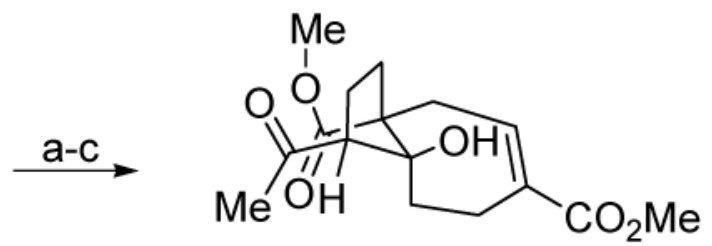

18 d, e $\checkmark$

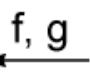

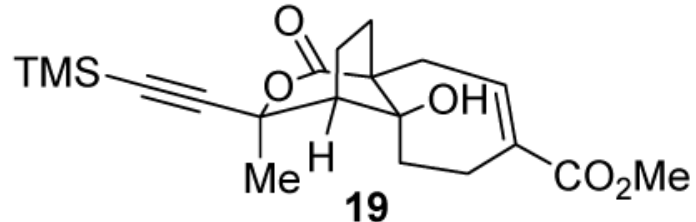

Scheme 4.

Completion of the Synthesis ${ }^{\text {a }}$

aConditions: (a) KOTMS, toluene, $120{ }^{\circ} \mathrm{C}, 30 \mathrm{~min}$, then $\mathrm{Me}_{2} \mathrm{SO}_{4}$, buffer (TsOH, Hünig's base 1:2), $100{ }^{\circ} \mathrm{C}, 5 \mathrm{~min}$. (b) Dess-Martin periodinane, $\mathrm{NaHCO}_{3}, \mathrm{CH}_{2} \mathrm{Cl}_{2}, 0{ }^{\circ} \mathrm{C}, 59 \%$ over 2 steps (73\% brsm). (c) DDQ, $\mathrm{pH}=7$ buffer, $\mathrm{CH}_{2} \mathrm{Cl}_{2}, 76 \%$. (d) $\mathrm{TMSC} \equiv \mathrm{CCeCl}_{2} \cdot 2 \mathrm{LiCl}, \mathrm{THF},-78{ }^{\circ} \mathrm{C}$, $87 \%$ (98\% brsm). (e) Otera's catalyst, ${ }^{12}$ toluene, $130{ }^{\circ} \mathrm{C}, 30 \mathrm{~min}, 94 \%$. (f) TBAF, THF, $0 \rightarrow 23$ ${ }^{\circ} \mathrm{C}, 87 \%$. (g) $\mathrm{Ac}_{2} \mathrm{O}, 8 \mathrm{~mol} \% \mathrm{Sc}(\mathrm{OTf})_{3}, 0{ }^{\circ} \mathrm{C}, 98 \%$. (h) $\mathrm{Bu}_{3} \mathrm{SnH}, 5 \mathrm{~mol} \% \mathrm{Pd}\left(\mathrm{PPh}_{3}\right)_{2} \mathrm{Cl}_{2}, \mathrm{THF}$, 90\%. (i) Iodide 21, $25 \mathrm{~mol} \% \mathrm{Pd}_{2} \mathrm{dba}_{3}$, Hünig's base, NMP, $62 \%$. 